\title{
Advanced treatment of effluent extended aeration process using biological aerated filter (BAF) with natural media: modification in media, design and backwashing process
}

\author{
Mohammad Malakootian ${ }^{1,2}$, Ali Toolabi ${ }^{3^{*}}$ (1) and Saeed Hosseini ${ }^{1}$
}

\begin{abstract}
Biological aerated filters (BAFs) have high filtration efficiency due to their tolerance of hydraulic and organic shocks are suitable for the treatment of complex and sanitary wastewater. In this study, for the first time, natural media of date kernel from Bam city was used as the BAF reactor media, with a meshing sand filter separated by a standard metal grid from the natural filter section used at the end of the reactor. This can be considered an innovation in the media and filtration. Aeration in the related reactor with $160 \mathrm{~cm}$ height was performed bilaterally as up-flow and continuously by nozzles throughout the reactor media. In this work, the actual effluent of the hospital wastewater treatment plant was employed as the inflow wastewater to the reactor, and its organic and inorganic parameters were measured before and after the treatment by the BAF reactor. The backwashing process was also studied in three ways: bottom backwashing (TB), top backwashing (BB), and top and bottom backwashing (TBBS), to determine the amount of water consumed and to achieve the desired result. According to the results obtained in this study, the removal efficiencies of inorganic and microbial contaminants, amoxicillin and azithromycin were obtained as follows: $\mathrm{BOD}_{5}$ : 98.48\%, COD: $92.42 \%, \mathrm{NO}_{3}^{-}$: 99.4\%, P: 93.3\%, Coliforms: $97 \%$, Color: 42.8\%, Turbidity: $95 \%$, Sulphate: 30\%, TSS: $98.9 \%$, Amoxicillin: 20\% and azithromycin: 13\%. In the backwashing process, the amount of water consumed in these three TB, BB, and TBBS methods were obtained 300, 164, and $118 \mathrm{~L}$, respectively, So, TBBS method was selected as the optimal method. Based on the results obtained in this study, it is concluded that the BAF process with natural date kernel has a high efficiency in removing organic and inorganic contaminants from hospital wastewater, also the concentration of most of the effluent parameters was less or in accordance with EPA standard.
\end{abstract}

Keywords: Hospital wastewaters, Natural media, Biological aerated filters, Backwashing

\section{Introduction}

Hospital wastewaters (HWW) are considered an important source of water contamination. These wastewaters contain large amounts of dangerous pollutants including pathogens, fats, proteins, carbohydrates, pharmaceuticals, resistant chemicals, and endocrine disrupters (Zou

\footnotetext{
*Correspondence: atoolabi@yahoo.com

${ }^{3}$ Department of Environmental Health Engineering, School of Public Health, Bam University of Medical Sciences, Bam, Iran

Full list of author information is available at the end of the article
}

2015; Liu et al. 2010). The concentration of micro-pollutants existing in these wastewaters is 4-150 times higher than that in urban wastewaters (Kovalova et al. 2013). Some components of hospital wastewater are genotoxic and carcinogenic to humans (Gurjar et al. 2019). These wastewaters can enter water sources, sediments, and soil through incomplete wastewater treatment systems (Huang et al. 2011; Gros et al. 2007, Navasero and Oatman 1989; Aboltina et al. 2017). Thus, due to the existence of diverse and complex compounds in hospital wastewaters, conventional wastewater treatment plants 
cannot completely remove them and advanced treatment methods should be used (Aboltina et al. 2017; Verlicchi et al. 2012; Nikoonahad et al. 2017). Biological aerated filters (BAFs) are a novel, flexible, and economical method with low footprint in the formation of active microbial biofilms and high organic charge (Lee et al. 2013; Liu et al. 2015; Antoniou et al. 2013; Bohm 2007; Shi et al. 2011). These filters are used as a desirable biological process for treating waste leachates, waste-containing pathogens, volatile organic compounds, nitrate, ammonium, phosphorus, suspended solids, acetate, fats, dyes, and nitro-aromatic compounds (Shi et al. 2011; Gehr et al. 2003; Sheng et al. 2010; Xu et al. 2012; Tudor and Lavric 2011). Filtration, absorption and biodegradation are important mechanisms of the BAF process in wastewater treatment (Nikoonahad et al. 2018).

The most important materials used in BAF media are sand, concrete, clay, shale, polyethylene, polystyrene, and plastic materials (Abouelela et al. 2019; Bilotta and Brazier 2008). The diameter of these media is about $4 \mathrm{~mm}$, operating at $10 \mathrm{~h}$ hydraulic retention time (Ding et al. 2018; Blumenthal et al. 2000; Amin et al. 2018). Nikoonahad in 2017 used a BAF reactor with a modified polystyrene medium in Iran, which was coated with sand as a new medium for advanced domestic wastewater treatment (Nikoonahad et al. 2017). Liu Jianguang in China treated hospital wastewater using BAF method in 2003 (Jianguang 2003). YI Biao et al. in 2007 treated urban wastewater applying a BAF reactor and achieved $94.7 \%$ BOD removal (Biao et al. 2007).

City of Bam in Kerman Province is located in southeastern Iran with the average rainfall of $56.7 \mathrm{~mm}$ per year, and producing 200,000 tons of dates. Date is a fruit from Phoenix dactylifera family. Date kernel has a length between 2.5 and $2.8 \mathrm{~cm}$, width of $0.8-0.9 \mathrm{~cm}$, and thickness of 0.5 to $0.6 \mathrm{~cm}$ (Zayed and Eisa 2014). Date kernel contains a large amount of nutrients for the growth of microorganisms (Besbes et al. 2004a).

In a study in Tunisia by Besbes et al. (2004b), chemical and physical properties of date kernel were analyzed. It was found that date kernel contains high amounts of protein and unsaturated fats such as oleic acid and carbohydrates, which are essential for the growth of living creatures (Besbes et al. 2004b). In Saudi Arabia, Al-Thubiani in 2017 evaluated date kernel powder as a probiotic material containing large amounts of lactobacillus paracasei (Althubiani and Ahmadkhan 2017). Thus, due to the presence of these nutrients in date kernel, in the present study, applicability of biological aerated filter (BAF) with natural date kernel media in the removal of nitrate, phosphate, total suspended solids (TSS), biological oxidation demand (BOD), chemical oxygen demand (COD), Color, sulphate, coliforms, turbidity, azithromycin and amoxicillin from the outflow effluents of Pastor Hospital in Bam city were evaluated. The research innovations include the use of natural date kernel media instead of synthetic media (such as polystyrene), do not need to add nutrients for biofilm growth due to the use of natural date kernel media, which is known to have nutrients for the growth of microorganisms, the use of BAF reactor with natural date kernel in hospital wastewater treatment as the first study done so far, obtaining outflow effluent from a very high quality reactor and the use of different media in the backwashing process.

\section{Materials and methods}

\section{Sampling and wastewater features}

In this study, Sampling of raw wastewater and effluent from wastewater treatment plant of Pastor Hospital in Bam city, Iran was performed. After sampling, the samples were transferred to a specialized laboratory for analysis. Based on the results obtained from raw wastewater, the amount of BOD, COD, TSS, nitrate, sulfate and phosphate were reported 320, 440, 970, 76, 1050 and $45 \mathrm{mg} / \mathrm{L}$, respectively. Also the amount of amoxicillin and azithromycin in raw wastewater were obtained 15 and 3, respectively. Other characteristics of raw wastewater and effluent are shown in Table 1.

\section{Reactor construction and operation}

In this study, a biological aerated filters (BAFs) reactor was used to treatment the effluent from the wastewater treatment plant. The hydraulic properties of the designed reactor are shown in Table 2. A cylindrical tube made of polyvinyl chloride with a height of $110 \mathrm{~cm}$ and inner diameter of $10 \mathrm{~cm}$ filled to the height of $60 \mathrm{~cm}$ from the date kernel natural media was used to fabricate the reactor (Fig. 1). The date kernel medium is a natural media containing sufficient amounts of date residues for the initial feeding of microorganisms (Chandrasekaran and Bahkali 2013).

In order for maintenance of the equilibrium of the main media and prevention of possible biofilm particle outflow, three clay layers with $0.2,0.4$, and $0.6 \mathrm{~mm}$ meshing and $20 \mathrm{~cm}$ height were placed, where the bottom of the reactor was separated by a metal filter of stainless steel in $0.1 \mathrm{~mm}$ diameter from the above section of the reactor. The inflow to the reactor was used as up-flow to save and facilitate energy. To review the impact of the reactor height on removal of the desired pollutants, a recovery valve was inserted every $25 \mathrm{~cm}$ from the tube length.

In order to check the pressure inside the reactor, a piezometer was used in it. The aeration was performed continuously by an external pump with the discharge of $0.3-0.9 \mathrm{~L} / \mathrm{m}^{2} \mathrm{~s}$. To wash the filter media and prevent filter obstruction as well as outflow of additional biomass 
Table 1 Characteristics of raw wastewater and effluent from wastewater treatment plant

\begin{tabular}{|c|c|c|c|}
\hline Parameter & Mean raw wastewater & EPA standards & Mean effluent \\
\hline $\mathrm{pH}$ & 7.8 & $6-9$ & 8.1 \\
\hline Temperature & $20 \pm 19$ & - & $2 \pm 18$ \\
\hline TSS (mg/L) & $15 \pm 970$ & 5 & $5 \pm 90$ \\
\hline $\mathrm{DO}(\mathrm{mg} / \mathrm{L})$ & $20 \pm 0.75$ & 2 & $2 \pm 2$ \\
\hline $\mathrm{BOD}_{5}(\mathrm{mg} / \mathrm{L})$ & $20 \pm 320$ & 10 & $15 \pm 100$ \\
\hline $\mathrm{COD}(\mathrm{mg} / \mathrm{L})$ & $25 \pm 440$ & 100 & $15 \pm 198$ \\
\hline $\mathrm{NO}_{3}^{-}(\mathrm{mg} / \mathrm{L})$ & $10 \pm 76$ & 50 & $5 \pm 30$ \\
\hline $\mathrm{PO}_{4}^{-}(\mathrm{mg} / \mathrm{L})$ & $12 \pm 45$ & 6 & $5 \pm 30$ \\
\hline Turbidity (NTU) & - & 50 & $2 \pm 10$ \\
\hline Color (TCU) & $45 \pm 890$ & 550 & $5 \pm 105$ \\
\hline Sulfate (mg/L) & $57 \pm 1050$ & 1500 & $20 \pm 600$ \\
\hline Coliforms (MPN) & $1000 \pm 1 \times 10^{7}$ & 1000 & $100 \pm 1660$ \\
\hline Amoxicillin (mg/L) & $3 \pm 15$ & - & $3 \pm 10$ \\
\hline Azithromycin (mg/L) & $20 \pm 3$ & - & $0.3 \pm 1.5$ \\
\hline
\end{tabular}

Table 2 Reactor hydraulic properties

\begin{tabular}{lll}
\hline Parameter & Unit & Value \\
\hline Hydraulic retention time & min & 60 \\
Wastewater flow rate & $\mathrm{L} / \mathrm{m}^{2} \mathrm{~s}$ & 0.22 \\
Back wash flow rate & $\mathrm{L} / \mathrm{m}^{2} \mathrm{~s}$ & 1.6 \\
Flow rate of aeration pump & $\mathrm{L} / \mathrm{m}^{2} \mathrm{~s}$ & 0.9 \\
Reverse aeration pump flow rate & $\mathrm{L} / \mathrm{m}^{2} \mathrm{~s}$ & 7.3 \\
Average organic loading & $\mathrm{Kg} \mathrm{COD} / \mathrm{m}^{3} \mathrm{~d}$ & 0.76 \\
Mean dissolved oxygen & $\mathrm{mg} / \mathrm{L}$ & 5 \\
Inlet discharge to the reactor & $\mathrm{mL} / \mathrm{L}$ & 100 \\
\hline
\end{tabular}

from the bottom of the reactor, backwashing was performed by an air pump with discharge of $8 \mathrm{~L} / \mathrm{m}^{2}$ s every 20 days for $20 \mathrm{~min}$. To avoid turbulence in the sand filter, the backwashing pump hose was connected to a oneway valve mounted in the middle of the stainless-steel filter. A 100-L tank was employed for balancing and for initial sedimentation of the effluent entering the reactor. The effluent in the tank was gravity-fed into a biological reactor by a number of control valves. To reach the end of the backwashing, the outflow effluent turbidity was measured continuously. Other specifications are listed in Table 2.

\section{Analytical methods}

For biological adaptation and biofilm formation on the date kernel media, the outflow effluent from the hospital was aerated on a BAF filter for 4 weeks. After biofilm formation, the surface morphology of biofilm was performed by Field Emission Scanning Electron
Microscopes (FESEM), the outflow of actual hospital treatment plant effluent was injected continuously at $100 \mathrm{~mL} / \mathrm{min}$ discharge from the top of the reactor. After satisfying the above conditions, all parameters of this study including; $\mathrm{pH}$, temperature, dissolved oxygen, oxidation potential, and analysis reduction were analyzed by multi-parameter HANNA (model, HI98196, made in Italy) (Romero et al. 2008), while turbidity was measured by $\mathrm{HACH}$ portable turbidimeter (model 2100Q). BOD 5 was also measured by BOD 6-chamber device (BOD Oxidirect manufactured by Lavi band company, Germany) (Beszédes et al. 2018).

COD was measured through standard reflux method (Vyrides and Stuckey 2009); and azithromycin and amoxicillin antibiotics were analyzed using high-performance liquid chromatography device (HPLC) as well as C18 specific column, mobile phase (95\% phosphate buffer and 5\% acetonitrile) (Cazorla-Reyes et al. 2014). TSS was analyzed via gravimetric method (Alkarkhi et al. 2008), coliforms (based on the most probable number of coliforms per $100 \mathrm{cc}$ ) (Evans et al. 1981), as well as nitrate and phosphate according to the procedures addressed in Water and Wastewater Standard Method. Eddy. "eddition", 23 (2017) (Metcalf et al. 1979). Based on Eq. (1), the efficiency of the BAF process in removing pollutants was obtained.

$$
\operatorname{Removal}(\%)=\left(\frac{C 0-C t}{C 0}\right) * 100,
$$

where: $C_{0}$, initial concentration of pollutant $(\mathrm{mg} / \mathrm{L}) ; \mathrm{C}_{\mathrm{t}}$, residual concentration of pollutant $(\mathrm{mg} / \mathrm{L})$. 


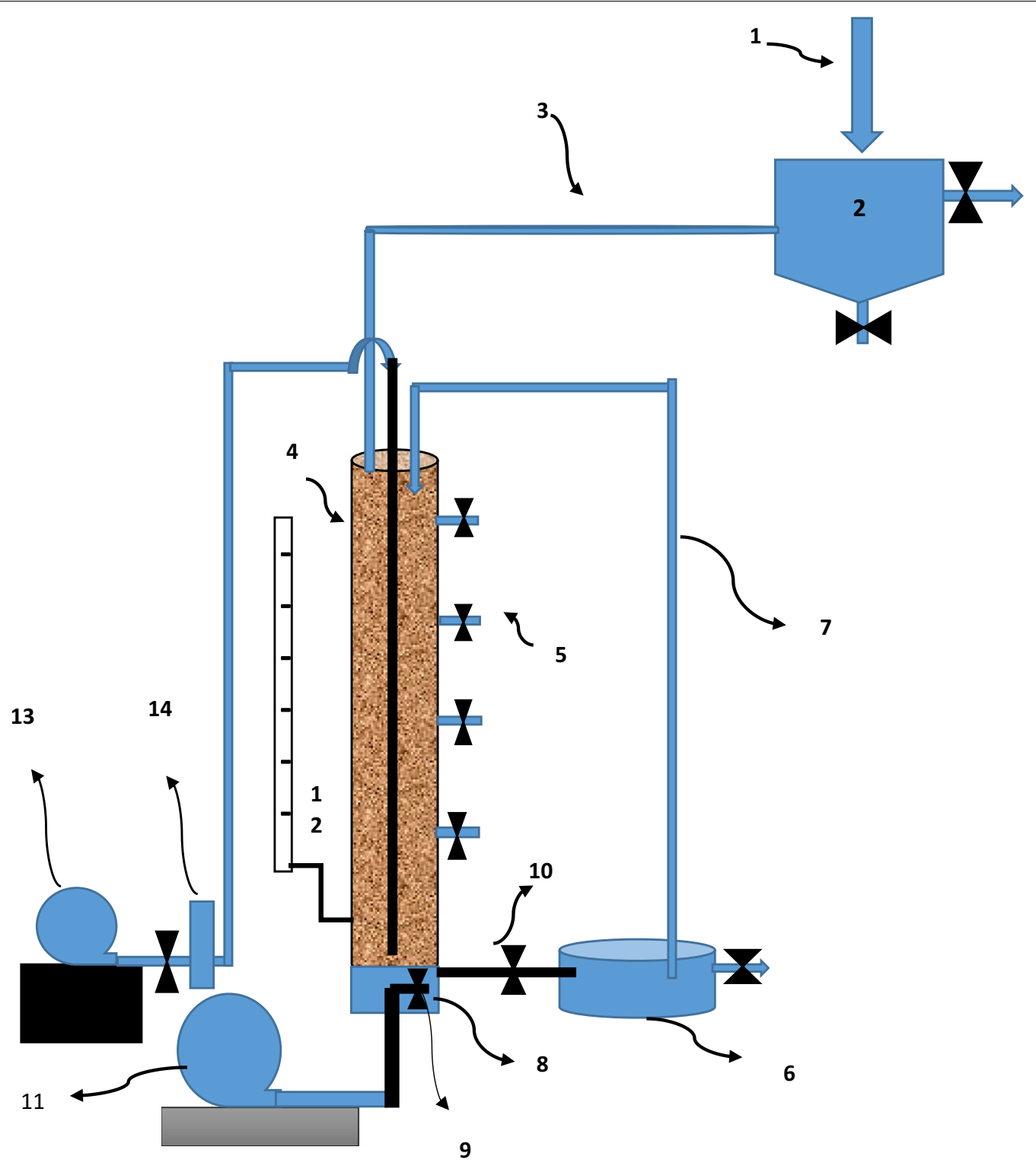

Fig. 1 Schematic of the BAF reactor (1. Wastewater Inlet 2. Primary settling tank 3. Wastewater inlet line 4. Reactor chamber 5. Sample valves 6. Secondary settling tank 7. Return sludge line 8. Sand filter 9. One-way valve 10. Effluent Valve 11. Backwash pump 12. Piezometer 13. Aeration pump 14. Aeration regulator)

\section{Backwashing process}

The backwashing process was performed based on the pressure drop in the piezometer between 13 and $17 \mathrm{~cm}$. Initially, the backwashing pump was turned on for $20 \mathrm{~min}$ and, during the washing, the effluent from the turbidity was evaluated until the desired turbidity was reached. The backwashing process was also studied in three ways: bottom backwashing (TB), top backwashing (BB), and top and bottom backwashing (TBBS), to determine the amount of water consumed and achieve the desired result. In all cases, the outflow turbidity was evaluated from the release valves. In the TBBS technique, backwash effluent flow rate through bottom and top valves was approximately $70 \%$ and $30 \%$, respectively. During steps one and two totally, nine backwashes were conducted in TB, BB, and TBBS methods; each one for three times. In each backwashing process, the air compressor with an air flow rate of $8 \mathrm{~L} / \mathrm{m}^{2} \mathrm{~s}$ was initially applied for $20 \mathrm{~min}$ to dislodge the solid germs and biological slug mass by creating turbulence in the media and silica layer. Then, the air flow was shut down and immediately clean water with a flow rate of $1.6 \mathrm{~L} /$ 
$\mathrm{m}^{2}$.s was applied from the same entrance to separate and drive the BAF sludge out.

\section{Preparation and analysis of date kernel}

Nutrient tests were performed to investigate the nutrients and other organic and inorganic constituents of the date kernel to be used as a natural substrate for the BAF reactor. The date kernels were firstly isolated and then collected from the palm mantle, and after repeated washing with warm water, the final rinse was deionized. Afterward, they were kept under the sun light for 2 days. Subsequently, they were dehydrated for $24 \mathrm{~h}$ at $50{ }^{\circ} \mathrm{C}$. The cores were then powdered through the mill and dissolved in $100 \mathrm{~mL}$ of chloroform and acetone and finally allowed to stand for $48 \mathrm{~h}$ at room temperature. After passing the homogeneous solution of Whitman filter, physicochemical and Brunauer-Emmett-Teller (BET) analyses were determined (Platat et al. 2014; Baliga et al. 2011). Mineral content $\left[\mathrm{N}, \mathrm{K}^{+}, \mathrm{Ca}^{2+}, \mathrm{Na}^{+}\right]$was determined by using the nitrate, potassium, calcium and sodium digital meter, model: Horiba (USA), Iron and manganese were determined using Atomic Absorption Spectrophotometer (Parvin et al. 2015; Sharif 2015).

\section{Statistical analysis}

Data on pollutant removal efficiency were analyzed by SPSS (ver. 22) software through one-way analysis of variance test.

\section{Results}

The results of the physicochemical and Brunauer-EmmettTeller (BET) properties tests of dates kernel

The results of the physicochemical properties of date kernel are shown in Table 3, and the results of date mineral analysis were as follows: sodium: 25.33, calcium 25.33,

Table 3 Physico-chemical properties of date kernels

\begin{tabular}{ll}
\hline Parameter & Value \\
\hline Ash content \% & 1.52 \\
Moisture \% & 2.33 \\
Volatile content \% & $65.4 \pm 3.5$ \\
Fixed carbon content \% & $25 \pm 3$ \\
C \% & 28 \\
N\% & 0.8 \\
Fat \% & 12 \\
Particle density Kg/m ${ }^{3}$ & 650 \\
Prosity \% & 24 \\
Total carbohydrate \% & 79.33 \\
Crude Fiber \% & 26.18 \\
Protein \% & 4.44 \\
pH & $4.7 \pm 0.3$ \\
\hline
\end{tabular}

manganese 4.5, potassium 0.6 and iron $43.76 \mathrm{eq} / \mathrm{L}$, which was the highest amount of mineral related to iron. Also, particle density and crude fiber content of date kernels were obtained $650 \mathrm{~kg} / \mathrm{m}^{3}$ and $26.18 \%$, respectively. The results of the Brunauer-Emmett-Teller (BET) properties of date kernel are shown in Table 4. According to the results obtained in Table 4, Total pore volume and mean pore diameter of date kernel were reported 0.0023731 $\mathrm{cm}^{3} \mathrm{~g}^{-1}$ and $9.4649 \mathrm{~nm}$, respectively.

\section{The field-emission scanning electron microscope of the date kernel}

The results of the field-emission scanning electron microscope (FESEM) of the biofilm formed on the date kernel are shown in Fig. 2. Date kernel surface morphology showed that the biofilm formed was very rough, bumps and protrusions. The size distribution of these protrusions was quite variable (range of $0.36-22.59 \mu \mathrm{m})$.

The results of biological filtration in removal of pollutants The results of biological filtration by date kernels are presented in Table 5. In this study, upon increasing the filtration height from 25 to $100 \mathrm{~cm}$, the removal efficiencies of inorganic and microbial contaminants, amoxicillin and azithromycin were obtained as follows: $\mathrm{BOD}_{5}: 98.48 \%$, COD: $92.42 \%, \mathrm{NO}_{3}^{-}$: 99.4\%, P: 93.3\%, Coliforms: $97 \%$, Color: 42.8\%, Turbidity: 95\%, Sulphate: 30\%, TSS: $98.9 \%$, Amoxicillin: 20\% and azithromycin: 13\%.

\section{Evaluating backwashing finishing time process}

Based on the pressure drop in the piezometer, the backwashing process was performed every 20 days. According to the results obtained in this study, the TB backwashing method was completed in 75 min, while in the BB method, the optimum turbidity was completed in $45 \mathrm{~min}$. In the TBBS method, the optimum turbidity removal rate was obtained within $20 \mathrm{~min}$. The amount of water consumed in these three TB, BB, and TBBS methods was 300,164 , and $118 \mathrm{~L}$, respectively. The lowest amount of water consumed for washing was related to the TBBS process.

Table 4 BET Plot of date kernel

\begin{tabular}{lll}
\hline Parameter & Value & Unit \\
\hline$V_{m}$ & 0.2304 & {$\left[\mathrm{~cm}^{3}(\mathrm{STP}) \mathrm{g}^{-1}\right]$} \\
$a_{\mathrm{s} \text { BET }}$ & 1.0029 & {$\left[\mathrm{~m}^{2} \mathrm{~g}^{-1}\right]$} \\
$C$ & 67.951 & \\
Total pore volume $\left(p / p_{0}=0.990\right)$ & 0.0023731 & {$\left[\mathrm{~cm}^{3} \mathrm{~g}^{-1}\right]$} \\
Mean pore diameter & 9.4649 & {$[\mathrm{~nm}]$} \\
\hline
\end{tabular}



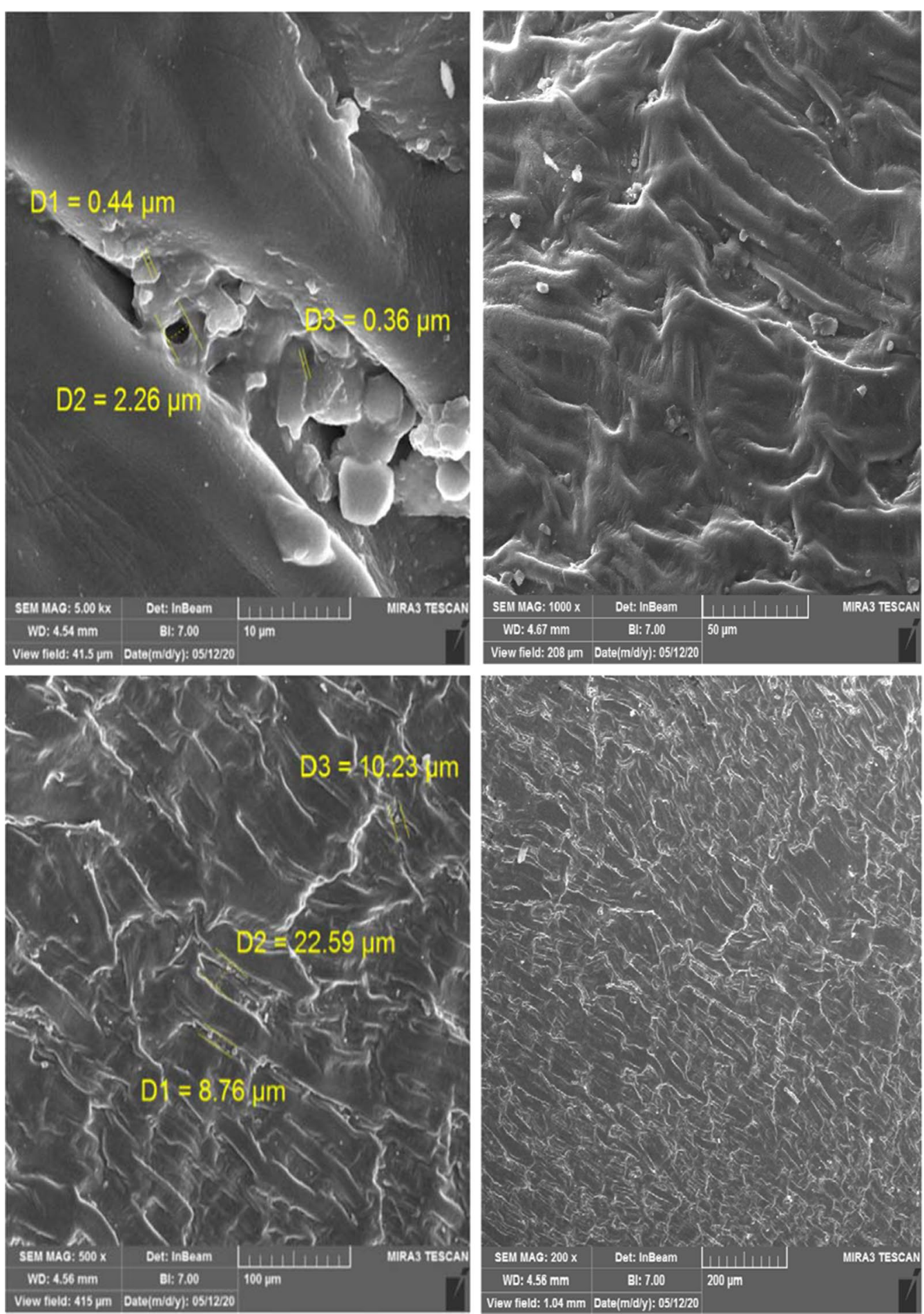

Fig. 2 FESEM of date kernel media

\section{Evaluating effluent backwashing return to reactor}

In this study, the effluent backwashing return to the reactor and its outflow was investigated over two threemonth periods and the results of the pollutant analysis were compared with the reactor outflow without the return of effluent, Table 6 . The lowest and highest COD removal efficiencies were related to Reactor output without return effluent and TBBS methods, respectively. The 
Table 5 Results of biological filtration by date kernels

\begin{tabular}{|c|c|c|c|c|c|c|c|}
\hline Parameter & $\begin{array}{l}\text { Inlet } \\
\text { wastewater to } \\
\text { the reactor }\end{array}$ & $\begin{array}{l}\text { Average output } \\
\text { of the reactor } \\
\text { at a height of } \\
25 \mathrm{~cm}\end{array}$ & $\begin{array}{l}\text { Average output } \\
\text { of the reactor } \\
\text { at a height of } \\
50 \mathrm{~cm}\end{array}$ & $\begin{array}{l}\text { Average output } \\
\text { of the reactor } \\
\text { at a height of } \\
75 \mathrm{~cm}\end{array}$ & $\begin{array}{l}\text { Average output } \\
\text { of the reactor } \\
\text { at a height of } \\
100 \mathrm{~cm}\end{array}$ & $\begin{array}{l}\text { Average output } \\
\text { from drain } \\
\text { valve reactor }\end{array}$ & $\begin{array}{l}\text { Average } \\
\text { final removal } \\
\text { percentage }\end{array}$ \\
\hline $\mathrm{PH}$ & 8.1 & 8.1 & 8.1 & 8.1 & $0.5 \pm 8.1$ & $1 \pm 7$ & - \\
\hline $\mathrm{DO}(\mathrm{mg} / \mathrm{L})$ & 2 & $0.2 \pm 5$ & $0.3 \pm 5$ & $0.3 \pm 5$ & $0.3 \pm 5$ & $0.3 \pm 5$ & - \\
\hline $\mathrm{BOD}_{5}^{-}(\mathrm{mg} / \mathrm{L})$ & $5 \pm 100$ & $5 \pm 80$ & $5 \pm 50$ & $5 \pm 20$ & $5 \pm 10$ & $0.6 \pm 3$ & 98.48 \\
\hline $\operatorname{COD}(\mathrm{mg} / \mathrm{L})$ & $10 \pm 198$ & $10 \pm 150$ & $7 \pm 70$ & $5 \pm 30$ & $5 \pm 20$ & $3 \pm 15$ & 92.42 \\
\hline $\mathrm{NO}_{3}^{-}(\mathrm{mg} / \mathrm{L})$ & $5 \pm 30$ & $2 \pm 20$ & $1.5 \pm 15$ & $1 \pm 8$ & $0.5 \pm 3$ & $0.3 \pm 0.6$ & 99.4 \\
\hline $\mathrm{PO}_{4}^{-}(\mathrm{mg} / \mathrm{L})$ & $3 \pm 15$ & $2 \pm 10$ & $1.5 \pm 8$ & $1 \pm 4$ & $0.8 \pm 2$ & $0.3 \pm 1$ & 93.3 \\
\hline Turbidity (NTU) & $0.5 \pm 10$ & $0.5 \pm 9$ & $0.5 \pm 8$ & $0.5 \pm 7$ & $0.5 \pm 6$ & 0.5 & 95 \\
\hline Color (TCU) & $10 \pm 105$ & $10 \pm 100$ & $10 \pm 80$ & $10 \pm 75$ & $10 \pm 65$ & $10 \pm 60$ & 42.8 \\
\hline Sulfate (mg/L) & $80 \pm 600$ & $80 \pm 580$ & $80 \pm 480$ & $80 \pm 450$ & $60 \pm 430$ & $50 \pm 420$ & 30 \\
\hline TSS (mg/L) & $0.2 \pm 90$ & $0.2 \pm 40$ & $0.2 \pm 22$ & $0.2 \pm 15$ & $0.2 \pm 9$ & $0.2 \pm 1$ & 98.9 \\
\hline ORP (mv) & +10 & +50 & +85 & +120 & +200 & +214 & - \\
\hline $\begin{array}{l}\text { Amoxicillin } \\
(\mathrm{mg} / \mathrm{L})\end{array}$ & $3 \pm 10$ & - & - & - & - & $1 \pm 8$ & 20 \\
\hline $\begin{array}{l}\text { Azithromycin } \\
(\mathrm{mg} / \mathrm{L})\end{array}$ & $0.3 \pm 1.5$ & - & - & - & - & $0.05 \pm 1.3$ & 13 \\
\hline
\end{tabular}

Table 6 Properties of effluent backwashing return to the reactor

\begin{tabular}{lllll}
\hline Method & BOD $(\mathbf{m g} / \mathbf{L})$ & COD (mg/L) & TSS(mg/L) & $\begin{array}{l}\text { Turbidity } \\
\text { (NTU) }\end{array}$ \\
\hline Reactor output without return & 3 & 15 & 1 & 0.5 \\
Reactor output with TB rotation & 2 & 13 & 1 & 0.5 \\
Reactor output with BB rotation & 2 & 13 & 1 & 0.5 \\
Reactor output with TBBS rotation & 2 & 12 & 1 & 0.5 \\
\hline
\end{tabular}

removal efficiency of other Parameters by the studied methods was slightly different.

\section{Discussion}

The results of the field-emission scanning electron microscope of the biofilm formed on the date kernel are shown in Fig. 2. Date kernel surface morphology showed that the biofilm formed was very rough, bumps and protrusions. The size distribution of these protrusions was quite variable (range of $0.36-22.59 \mathrm{um}$ ). Based on the results obtained in this study, The FESEM technique showed that, Colony growth and biofilm formation on date kernels are higher than polymeric materials. Also, in the present study, the removal efficiency of contaminants from wastewater was higher than, other studies using polymeric and synthetic media (Nikoonahad et al. 2018). According to Nikoonahad et al. study in 2017, it has been reported that the rough and irregular surface of media has provided a suitable site for biological attached growth (Nikoonahad et al. 2017).
In this study, BET test was used to measure the amount of porosity and effective surfaces of the date bed, with its results shown in Table 4. Based on the results, it was observed that there was a direct relationship between the amount of bed pores and the amount of adsorption and decomposition of contaminants. According to the results presented in Table 5 , the removal efficiencies of $\mathrm{BOD}_{5}$, $\mathrm{COD}, \mathrm{NO}_{3}^{-}$, P, Total Coliforms, Color, Turbidity, Sulphate, TSS, Amoxicillin and azithromycin were obtained, 98.48, 92.42, 99.4, 93.3, 97, 42.8, 95, 30, 98.9, 20 and 13\%, respectively. Thus, the concentration of pollutants in the effluent was observed in the range of environmental standards.

Liu et al. (2010) in China treated domestic wastewater by a BAF reactor with oyster shell media as well as plastic ball media. They achieved $\mathrm{COD}, \mathrm{PO}_{4}$, and $\mathrm{NO}_{3}^{-}$removal efficiency of $85.1 \%, 98.1 \%$, and $79.9 \%$ for oyster shell media and 80\%, 93.7\%, and $90.6 \%$ for plastic ball media, respectively (Liu et al. 2010).

Abouelela et al. (2019) in Egypt used a BAF reactor to treat domestic wastewater and reached the BOD and 
COD removal efficiency of $92 \%$ and $89 \%$, respectively (Abouelela et al. 2019), In the present study, it was found that the removal efficiency of contaminants was higher than other studies, the reason for which could be the use of natural date kernel media. Also, ORP was reported at lower $+50 \mathrm{mV}$ depth and, with the increase in the reactor floor height, ORP levels were increased as well. In aerobic processes due to increased dehydrogenase enzyme activity, ORP levels also increased, improving and facilitating organic material degradation (Toolabi et al. 2017, 2018, 2019).

According to Rebecca's Moore's studies carried out in 2001 in the UK, as the media depth increased, so did the removal efficiency of parameters such as BOD, COD, and TSS due to longer retention time and greater opportunity for the degradation of pollutants by biofilm microorganisms (Moore et al. 2001). BAF reactors have both oxic and anoxic zones. Anoxic zones are suitable for nitrification and denitrification, removing organic matter and nitrate, as well as removing oxic residual zones of organic matter and ammonium (Pramanik et al. 2012). Phosphorus removal from wastewater is accomplished by sedimentation and absorption. So, in the current study we observed enhanced removal efficiency for all pollutants with increasing retention time and reactor length.

Given the high per capita production of dates in Bam, it is important to use natural date kernel media for secondary high-quality treatment of wastewater and effluent for discharge into receiving waters. Due to the interstices on the kernel and large amount of residual nutrients in the kernel shell, or so-called endocarp, it is a suitable environment for the growth of microorganisms decomposing organic matter of wastewater (Ravi 2017; Dehdivan and Panahi 2017; Platat et al. 2014; Baliga et al. 2011).In this study, according to the results obtained, date kernel contains a large amount of minerals such as calcium, magnesium, phosphorus, iron, zinc, and flavonoids. Similarly, in the experiments performed on Bam Mazafati date kernel by Dehdivan et al. (2017) in Iran, it was found that date kernels contained large amounts of organic and mineral nutrients (Dehdivan and Panahi 2017).

According to the results obtained in this study, the TB backwashing method was completed in $75 \mathrm{~min}$, while in the BB method, the optimum turbidity was completed in $45 \mathrm{~min}$. In the TBBS method, the optimum turbidity removal rate was obtained within $20 \mathrm{~min}$. The amount of water consumed in these three TB, BB, and TBBS methods was 300,164 , and $118 \mathrm{~L}$, respectively. The lowest amount of water consumed for washing was related to the TBBS process, consequently this method was selected as the optimal one. In the study by Nikoonahad (2017) on a BAF reactor with polystyrene media about backwashing media, TBBS method with 35 min was selected as an optimum method (Nikoonahad et al. 2017).

In this study, to prevent biofilm outflow, a three-layer sand grading filter was considered, which would further remove the turbidity of the outflow effluent from the reactor. The date kernel as a food source for the growth of microorganisms as well as the presence of viscous layer compounds on the date kernel slowed down the movement of wastewater, resulting in small water ponds throughout the reactor (Song et al. 2014). In addition, further meshing and degradation of pollutants were observed by biofilm.

In this work, the effluent backwashing return to the reactor and its outflow was investigated over two threemonth periods. Then, the results of the pollutant analysis were compared with the reactor outflow without the return of effluent. According to the data in Table 6, slight changes were observed in the removal of pollutant parameters with the return of the backwash effluent to the BAF reactor due to the increased presence of microorganisms in the effluent. In aerobic wastewater treatment processes, the observation of protozoan and metazoan microorganisms is an indication of adapted microbial biofilm for the decomposition of wastewater organic matters (Kamika and Momba 2013). In wastewater treatment by the attached growth methods, we usually see the presence of protozoa, metazoan, mastigamoeba, vorticella and rotifer (Madoni 2011).

In this study, the removal efficiency of amoxicillin and azithromycin by BAF process were observed $20 \%$ and $13 \%$, respectively. Antibiotics are not easily degraded via biological processes due to their complex structure and require complex processes such as photocatalytic processes as well as advanced oxidation for complete removal (Manaia et al. 2018). In this study, wastewater treatment was performed by aerated biological filters with modifications and innovations in media (date kernel) as well as three methods of backwashing and outflow effluent evaluation. Here, very favorable results were achieved in the removal of indicator pollutants as well as other physical and chemical parameters. Some of the results were concerned with the percentage of TSS $(1 \mathrm{mg} / \mathrm{L})$, turbidity $(0.5 \mathrm{NTU})$, sulphate $(420 \mathrm{mg} / \mathrm{L})$, nitrate $(0.18 \mathrm{mg} / \mathrm{L})$, COD $(14.9 \mathrm{mg} / \mathrm{L})$, $\mathrm{BOD}_{5}(1.52 \mathrm{mg} / \mathrm{L})$, and phosphate $(2 \mathrm{mg} / \mathrm{L})$, which were in accordance with EPA guidelines, as in Tables 1 and 5. Given that the natural medium of date kernels has a porous surface and contains nutrients for the growth of microorganisms, so, in comparison with other synthetic media, it never requires adding nutrients for the growth of microorganisms and biofilm formation. In the present study, it was found that the BAF reactor with natural media of date kernel via 
filtration, absorption and biodegradation mechanisms causes wastewater treatment. Effluent recirculation of backwashing in all the three methods of top, bottom and top-bottom backwashing, as compared in Table 6, showed no significant effect on the removal of pollutants in these three methods as well as effluent without recirculation method. In the present study, also, oxidation and reduction potential was measured in order to prevent anoxic media along the reactor at different heights. The results ranged from $+10 \mathrm{mV}$ in raw wastewater to $+214 \mathrm{mV}$ in outflow effluent, indicating optimum aeration performance. The proposed aeration biological filter system can be used as an effective method for secondary treatment of wastewater effluent.

\section{Abbreviations}

HRT: Hydraulic retention time; BAF: Biological aerated filters; COD: Chemical oxygen demand; ORP: Oxidation reduction potential; HPLC: High performance liquid chromatography; HWW: Hospital waste waters; BB: Bottom backwashing; TB: Top backwashing; TBBS: Top and bottom backwashing.

\section{Acknowledgements}

Authors Acknowledge the School of Public Health Bam, for providing the materials and Laboratory equipment used in this study.

\section{Authors' contributions}

AT, SH carried out experiments; MM and AT conceived and designed the experiments; $\mathrm{SH}$ and MM made a substantial contribution to the analysis and interpretation of the data. Presented; MM, AT and SH wrote the paper. All authors read and approved the final manuscript.

\section{Funding}

Not applicable.

\section{Availability of data and materials}

Not applicable.

\section{Declarations}

Ethics approval and consent to participate

Not applicable.

\section{Consent for publication}

Not applicable.

\section{Competing interests}

Not applicable.

\section{Author details}

${ }^{1}$ Environmental Health Engineering Research Center, Kerman University of Medical Sciences, Kerman, Iran. ${ }^{2}$ Department of Environmental Health Engineering, Faculty of Public Health, Kerman University of Medical Sciences, Kerman, Iran. ${ }^{3}$ Department of Environmental Health Engineering, School of Public Health, Bam University of Medical Sciences, Bam, Iran.

Received: 29 January 2021 Accepted: 24 June 2021

Published: 5 July 2021

\section{References}

Aboltina B, Aboltins A, Adadi P, Akhmedov S, Al-tawaha A, Ataei R, Bartolini S, Bi J, Birgere L, Blumberga D (2017) Anaerobic co-digestion of oil refinery wastewater and chicken manure to produce biogas, and kinetic parameters determination in batch reactors. Agron Res 15(5):1983-1996

Abouelela EL, Hellal MS, Aly OH, Aboelenin SA (2019) Decentralized wastewater treatment using passively aerated biological filter. Environ Technol 40:250-260

Althubiani AS, Ahmadkhan MS (2017) The prebiotic properties of date palm (Phoenix dactylifera $\mathrm{L}$ ) seeds in stimulating probiotic lactobacillus. J Pure Appl Microbiol 11:1675-1686

Alkarkhi AF, Ahmad A, Ismail N, Easa A, Omar K (2008) Assessment of surface water through multivariate analysis. J Sustain Dev 1:27-33

Amin MM, Bina B, Ebrahimi A, Yavari Z, Mohammadi F, Rahimi S (2018) The occurrence, fate, and distribution of natural and synthetic hormones in different types of wastewater treatment plants in Iran. Chin J Chem Eng 26:1132-1139

Antoniou M, Hey G, Vega S, Spiliotopoulou A, Fick J, Tysklind M, Lacour J, Andersen H (2013) Required ozone doses for removing pharmaceuticals from wastewater effluents. Sci Tot Environ 456:42-49

Baliga MS, Baliga BRV, Kandathil SM, Bhat HP, Vayalil PK (2011) A review of the chemistry and pharmacology of the date fruits (Phoenix dactylifera L.). Food Res Int 44:1812-1822

Besbes S, Blecker C, Deroanne C, Bahloul N, Lognay G, Ne D, Attia H (2004a) Date seed oil: phenolic, tocopherol and sterol profiles. J Food Lipids 11:251-265

Besbes S, Blecker C, Deroanne C, Drira N, Attia H (2004b) Date seeds: chemical composition and characteristic profiles of the lipid fraction. Food Chem 84:577-584

Beszedes S, Jákói Z, Lemmer B, Hodúr C (2018) Enhanced biodegradability of dairy sludge by microwave assisted alkaline and acidic pre-treatments. Rev Agricult Rural Dev 7:92-97

Biao Y, Tao T, Peng Z (2007) Application of biofor baf to municipal sewage treatment. J China Water Wastewater 20:1-12

Bilotta G, Brazier R (2008) Understanding the influence of suspended solids on water quality and aquatic biota. Water Res 42:2849-2861

Blumenthal UJ, Mara D, Peasey A, Ruiz-palacios G, Stott R (2000) Guidelines for the microbiological quality of treated wastewater used in agriculture: recommendations for revising who guidelines. Bull World Health Organ 78:1104-1116

Böhm R (2007) Pathogenic agents. In: Waste management series 8, chap 9. Elsevier, pp 177-198

Cazorla R, Romero G, Frenich A, Maresca M, Vidal J (2014) Simultaneous analysis of antibiotics in biological samples by ultra high performance liquid chromatography-tandem mass spectrometry. J Pharm Biomed Anal 89:203-212

Chandrasekaran M, Bahkali AH (2013) Valorization of date palm (Phoenix dactylifera) fruit processing by-products and wastes using bioprocess technology-review. Saudi J Biol Sci 20:105-120

Dehdivan N, Panahi B (2017) Physicochemical properties of seeds and seeds oil extracted from iranian date palm cultivars. Biol Forum Int I 9:139-144

Ding P, Chu L, Wang J (2018) Advanced treatment of petrochemical wastewater by combined ozonation and biological aerated filter. Environ Sci Pollut Res 25:9673-9682

Evans T, Lechevallier M, Waarvick C, Seidler R (1981) Coliform species recovered from untreated surface water and drinking water by the membrane filter, standard, and modified most-probable-number techniques. Appl Environ Microbiol 41:657-663

Gehr R, Wagner M, Veerasubramanian P, Payment P (2003) Disinfection efficiency of peracetic acid, UV and ozone after enhanced primary treatment of municipal wastewater. Water Res 37:4573-4586

Gros M, Petrović M, Barceló D (2007) Wastewater treatment plants as a pathway for aquatic contamination by pharmaceuticals in the Ebro river basin (northeast Spain). Environ Toxicol Chem Int J 26:1553-1562

Gurjar D, Singh R, Kaur R, Singh K (2019) Short-term impact of wastewater irrigation on chemical soil health in tuberose (Polianthes tuberosa). Indian J Agric Sci 89:439-444

Huang G, Meng F, Zheng X, Wang Y, Wang Z, Liu H, Jekel M (2011) Biodegradation behavior of natural organic matter (nom) in a biological aerated filter (baf) as a pretreatment for ultrafiltration (uf) of river water. Appl Microbiol Biotechnol 90:1795-1803

Jianguang $L$ (2003) Experiment on aerated biofilter treating hospital wastewater. Water Wastewater Eng 4:1-13 
Kamika I, Mn M (2013) Assessing the resistance and bioremediation ability of selected bacterial and protozoan species to heavy metals in metal-rich industrial wastewater. BMC Microbiol 13:28

Kovalova L, Siegrist H, Von G, Eugster J, Hagenbuch M, Wittmer A, Moser R, Mcardell C (2013) Elimination of micropollutants during post-treatment of hospital wastewater with powdered activated carbon, ozone, and UV. Environ Sci Technol 47:7899-7908

Lee S, Bai H, Liu Z, Sun D (2013) Novel-structured electrospun Tio2/Cuo composite nanofibers for high efficient photocatalytic cogeneration of clean water and energy from dye wastewater. Water Res 47:4059-4073

Liu YX, Yang TO, Yuan D, Wu Y (2010) Study of municipal wastewater treatment with oyster shell as biological aerated filter medium. Desalination 254:149-153

Liu T, Liu Z, Zhang R, Wang Y, Van B, Wang X (2015) Fabrication of a thin film nanocomposite hollow fiber nanofiltration membrane for wastewater treatment. J Membr Sci 488:92-102

Madoni P (2011) Protozoa in wastewater treatment processes: a minireview. Italian J Zool 78:3-11

Manaia C, Rocha J, Scaccia N, Marano R, Radu E, Biancullo F, Cerqueira F, Fortunato G, lakovides I, Zammit I (2018) Antibiotic resistance in wastewater treatment plants: tackling the black box. Environ Int 115:312-324

Metcalf L, Eddy H, Tchobanoglous G (1979) Wastewater engineering: treatment, disposal, and reuse. McGraw-Hill, New York

Moore R, Quarmby J, Stephenson T (2001) The effects of media size on the performance of biological aerated filters. Water Res 35:2514-2522

Navasero R, Oatman E (1989) Life history, immature morphology and adult behavior Oftelenomus solitus [hymenoptera: scelionidae]. Entomophaga 34:165-177

Nikoonahad A, Ghaneian MT, Mahvi AH, Ehrampoush MH, Ebrahimi A, Lotfi MH, Salamehnejad S (2017) Application of novel modified biological aerated filter (mbaf) as a promising post-treatment for water reuse: modification in configuration and backwashing process. J Environ Manage 203:191-199

Nikoonahad A, Mahvi AH, Ghaneian MT, Ehrampoush MH, Ebrahimi A, Lotfi $\mathrm{MH}$ (2018) Synthesis of polystyrene coated by sand (pcs) as a novel media in modified biological aerated filters (baf) for advanced municipal wastewater treatment: a comparative assessment. Desalination Water Treat 106:72-79

Parvin S, Easmin D, Sheikh A, Biswas M, Sharma S, Jahan M, Islam M, Roy N, Shovon M (2015) Nutritional analysis of date fruits (Phoenix dactylifera L.) in perspective of Bangladesh. Am J Life Sci 3:74-278

Platat C, Habib H, Al Maqbali F, Jaber N, Ibrahim W (2014) Identification of date seeds varieties patterns to optimize nutritional benefits of date seeds. J Nutr Food Sci 8:2

Pramanik BK, Fatihah S, Shahrom Z, Ahmed E (2012) Biological aerated filters (bafs) for carbon and nitrogen removal: a review. J Eng Sci Technol 7:428-446

Ravi L, Sundar R, Segaran G, Shankar S, Settu S (2017) bioactivity of phoenix dactylifera seed and its phytochemical analysis. Int J Green Pharm 11:292-297

Romero A, Santos A, Tojo J, Rodriguez A (2008) Toxicity and biodegradability of imidazolium ionic liquids. J Hazard Mater 151:268-273

Sharif Hossain A (2015) Dried dates fruit and its biochemical and nutrient content: uses as diabetic food. Asian J Clin Nutr 7:90-95

Sheng G, Yu H, Li X (2010) Extracellular polymeric substances (eps) of microbial aggregates in biological wastewater treatment systems: a review. Biotechnol Adv 28:882-894

Shi L, Zhang X, Chen Z (2011) Removal of chromium (vi) from wastewater using bentonite-supported nanoscale zero-valent iron. Water Res 45:886-892

Song X, Xue X, Chen D, He P, Dai X (2014) Application of biochar from sewage sludge to plant cultivation: influence of pyrolysis temperature and biochar-to-soil ratio on yield and heavy metal accumulation. Chemosphere 109:213-220

Toolabi A, Malakootian M, Ghaneian MT, Esrafili A, Ehrampoush MH, Askarshahi M, Tabatabaei M (2018) Modeling photocatalytic degradation of diazinon from aqueous solutions and effluent toxicity risk assessment using Escherichia coli LMG 15862. Amb Exp 8:59

Toolabi A, Malakootian M, Ghaneian MT, Esrafili A, Ehrampoush MH, Askarshahi M, Tabatabaei M, Khatami M (2019) Optimizing the photocatalytic process of removing diazinon pesticide from aqueous solutions and effluent toxicity assessment via a response surface methodology approach. Rend Lincei Sci Fis Nat 30:155-165

Toolabi A, Malakootian M, Ghaneian MT, Esrafili A, Ehrampoush MH, Tabatabae M, Askarshahi M (2017) Optimization of photochemical d ecomposition acetamiprid pesticide from aqueous solutions and effluent toxicity assessment by Pseudomonas aeruginosa BCRC using response surface methodology. Amb Exp 7:159

Tudor R, Lavric V (2011) Dual-objective optimization of integrated water/ wastewater networks. Comput Chem Eng 35:2853-2866

Verlicchi P, AlAukidy M, Galletti A, Petrovic A, Barceló D (2012) Hospital effluent: investigation of the concentrations and distribution of pharmaceuticals and environmental risk assessment. Sci Tot Environ 430:109-118

Vyrides I, Stuckey D (2009) A modified method for the determination of chemical oxygen demand (cod) for samples with high salinity and low organics. Biores Technol 100:979-982

Xu P, Zeng G, Huang DL, Feng C, Hu S, Zhao MH, Lai C, Wei Z, Huang C, Xie G (2012) Use of iron oxide nanomaterials in wastewater treatment: a review. Sci Tot Environ 424:1-10

Zayed MF, Eisa W (2014) Phoenix dactylifera L. leaf extract phytosynthesized gold nanoparticles; controlled synthesis and catalytic activity. Spectrochim Acta Part A Mol Biomol Spectrosc 121:238-244

Zou X (2015) Combination of ozonation, activated carbon, and biological aerated filter for advanced treatment of dyeing wastewater for reuse. Environ Sci Pollut Res 22:8174-8181

\section{Publisher's Note}

Springer Nature remains neutral with regard to jurisdictional claims in published maps and institutional affiliations.

\section{Submit your manuscript to a SpringerOpen ${ }^{\circ}$ journal and benefit from:}

- Convenient online submission

- Rigorous peer review

- Open access: articles freely available online

- High visibility within the field

- Retaining the copyright to your article

Submit your next manuscript at springeropen.com 